\title{
Serum Procalcitonin Correlates with Renal Function in Hepatitis B Virus-Related Acute-on-Chronic Liver Failure
}

\author{
Weiyang Zhenga Xue Liang ${ }^{a}$ Liyan Shuia Bingjue Yea Guohua Lou ${ }^{a}$ \\ Yanning Liu ${ }^{a}$ Min Zhenga,b \\ The State Key Laboratory for Diagnosis and Treatment of Infectious Diseases, The First Affiliated \\ Hospital, Zhejiang University, Hangzhou, Collaborative Innovation Center for Diagnosis and Treatment \\ of Infectious Diseases, Hangzhou, ${ }^{\mathrm{b}} \mathrm{Clinical}$ Research Center for Hepatobiliary and Pancreatic Diseases \\ of Zhejiang Province, Hangzhou, China
}

\section{Key Words}

Acute-on-chronic liver failure $\cdot$ Procalcitonin $•$ Creatinine $\bullet$ Glomerular filtration rate

\begin{abstract}
Background/Aims: To investigate the relationship between elevated serum procalcitonin $(P C T)$ and renal function in hepatitis B virus-related acute-on-chronic liver failure (HBV-ACLF). Methods: HBV-ACLF patients $(n=201)$ presenting to the State Key Laboratory for Diagnosis and Treatment of Infectious Diseases, The First Affiliated Hospital, Zhejiang University, from January 2013 to November 2016 were categorized into three groups according to serum PCT levels: (i) normal group ( $n=74$ ) had PCT of $\leq 0.5 \mathrm{ng} / \mathrm{mL}$; (ii) elevated group $(n=85)$ had PCT in the range $0.5-1.0 \mathrm{ng} / \mathrm{mL}$; and (iii) highly elevated group $(\mathrm{n}=42)$ had PCT of $>$ $1.0 \mathrm{ng} / \mathrm{mL}$. Thirty-five cases received standard care after admission. Serum PCT levels and renal function were determined during a two-week follow-up. Results: Significant increases in serum creatinine $(\mathrm{Cr})$ were recorded in male and female patients in the elevated group and highly elevated group compared with the normal group $(P<0.05)$. In addition, serum $\mathrm{Cr}$ levels in male and female patients were significantly higher in the highly elevated group than in the elevated group $(P<0.05)$. The glomerular filtration rate $(G F R)$ was significantly lower in the highly elevated group $(\mathrm{P}<0.05)$ and this group had the highest risk of altered $\mathrm{Cr}(45.9 \%$ in males; $80 \%$ in females) and abnormal GFR (37.5\%). Serum PCT levels correlated significantly with all renal function parameters including homocysteine (Hcy), GFR, $\mathrm{Cr}$, blood urea nitrogen, uric acid, and cystatin $C$ at baseline and during treatment. Univariate and multivariate analyses indicated that serum PCT was a strong predictor of renal dysfunction. Conclusion: Serum PCT is closely related to renal dysfunction in HBV-ACLF.




\section{Cellular Physiology Cell Physiol Biochem 2018;50:1794-1803

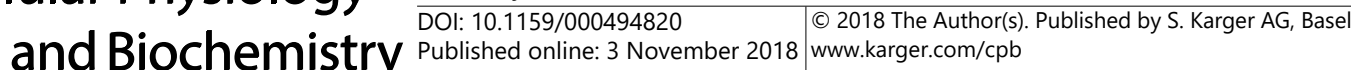 \\ Zheng et al.: PCT and Renal Function in HBV-ACLF}

\section{Introduction}

Patients with hepatitis B virus-related acute-on-chronic liver failure (HBV-ACLF) show significantly higher 28-day mortality than patients with non-HBV-ACLF [1]. Renal dysfunction is known as an independent predictor of mortality in HBV-ACLF [2]. Therefore, the identification of factors associated with renal dysfunction may contribute to determining the prognosis of HBV-ACLF patients.

High levels of serum procalcitonin (PCT), a calcitonin precursor hormone, have been found in patients with bacterial infections $[3,4]$. Furthermore, elevated serum PCT levels have been reported to show pro-inflammatory effects and increase mortality rates in a sepsis model [5], while these effects are prevented via the inhibition of PCT expression [6]. Interestingly, serum PCT is also elevated in HBV-ACLF patients [7]. However, little is known about the correlation between serum PCT and renal dysfunction in HBV-ACLF patients. In this study, serum PCT was measured in HBV-ACLF patients to evaluate the association between serum PCT and renal function in these patients.

\section{Materials and Methods}

\section{Patients}

HBV-ACLF patients presenting to the State Key Laboratory for Diagnosis and Treatment of Infectious Diseases, The First Affiliated Hospital, Zhejiang University, were analyzed from January 2013 to November 2016. ACLF patients aged $\geq 18$ years with chronic HBV infection were included in this study. HBV infection was defined as detectable hepatitis B surface antigen (HBsAg) and HBV DNA for at least 6 months. HBVACLF is defined as an acute hepatic insult manifesting as jaundice (serum bilirubin $\geq 5 \mathrm{mg} / \mathrm{dL}$ ) complicated by coagulopathy (international normalized ratio [INR] $\geq 1.5$ or prothrombin activity $<40 \%$ ) within 4 weeks and clinical ascites and/or encephalopathy in a patient with previously diagnosed or undiagnosed HBVrelated chronic liver disease/cirrhosis, in association with a high 28-day mortality rate [1]. The exclusion criteria were as follows: patients co-infected with other hepatitis viruses (e.g. HAV, HCV, HDV and HEV) and/ or human immunodeficiency virus; patients with a history of excessive alcohol consumption ( $>40 \mathrm{~g} /$ day); patients with a history of liver allograft or malignancy such as hepatocellular carcinoma; and patients with signs of bacterial infection. Bacterial infection was diagnosed as described previously [7].

\section{Grouping}

HBV-ACLF patients $(n=201)$ were categorized into three groups according to serum PCT levels: (i) normal group ( $\mathrm{n}=74$ ) with PCT of $\leq 0.5 \mathrm{ng} / \mathrm{mL}$; (ii) elevated group $(\mathrm{n}=85)$ with PCT in the range $0.5-1.0$ $\mathrm{ng} / \mathrm{mL}$; and (iii) highly elevated group $(\mathrm{n}=42)$ with PCT of $>1.0 \mathrm{ng} / \mathrm{mL}$. Thirty-five cases received standard care after admission. Serum PCT and renal function parameters were determined during a two-week followup.

\section{Bacterial culture and measurement of serum PCT}

Peripheral blood samples for culture were obtained from separate venipuncture sites at admission and during treatment. All samples were incubated at $35.8{ }^{\circ} \mathrm{C}$ in an appropriate atmosphere. Serum PCT concentrations were determined through an automated immunofluorescence assay using a Kryptor analyzer (Brahms, Hennigsdorf, Germany).

\section{Data collection}

We reviewed the medical records of all patients participating in this study using data obtained exclusively from our hospital's electronic medical records and verification was provided independently by two of the authors. All of the biochemical and serological markers were detected at The First Affiliated Hospital of Zhejiang Medical University, including liver serological tests [i.e. alanine aminotransferase (ALT), aspartate aminotransferase (AST), and total bilirubin (TB)], hematological tests (i.e., INR), routine blood 


\section{Cellular Physiology Cell Physiol Biochem 2018;50:1794-1803 \begin{tabular}{ll|l} 
and Biochemistry & $\begin{array}{l}\text { DOl.1159/000494820 } \\
\text { Published online: } 3 \text { November } 2018\end{array}$ & $\begin{array}{l}\text { 2018 The Author(s). Published by S. Karger AG, Basel } \\
\text { wwer.com/cpb }\end{array}$ \\
\cline { 2 - 3 }
\end{tabular} \\ Zheng et al.: PCT and Renal Function in HBV-ACLF}

examinations [i.e., white blood cell count, and percentage of neutrophils], as well as renal function tests [i.e., serum creatinine [Cr], glomerular filtration rate [GFR], cystatin C (CYC), blood urea nitrogen (BUN), and uric acid (UA)]. These studies were performed using standard methods in a clinical setting. The Model for End-Stage Liver Disease (MELD) score was calculated as follows: $9.6 \times \log _{\mathrm{e}}$ [creatinine $\left.(\mathrm{mg} / \mathrm{dL})\right]+3.8+$ $\log _{\mathrm{e}}$ [bilirubin $\left.(\mathrm{mg} / \mathrm{dL})\right]+11.2 \times \log _{\mathrm{e}}(\mathrm{INR})+6.43 \times$ (etiology: 0 if cholestatic or alcoholic, 1 otherwise) [8]

\section{Statistical analysis}

All data were analyzed in SPSS 17.0 (Chicago, IL). Continuous variables are presented as means \pm standard deviation, and categorical variables are presented as median values with interquartile ranges. Inter-group comparisons were performed using Student's $t$-test. Associations between dichotomic or linear variables were assessed by logistic or linear regression models, respectively. Multivariate models were obtained by stepwise forward selection, using $P>0.1$ for removal from the model. Differences between two categorical variables were assessed by chi-square tests. The diagnostic accuracy was expressed as the area under the receiver operating characteristic curve (AUC) derived from logistic regression analysis. $P<0.05$ was considered statistically significant.

\section{Results}

\section{Patient characteristics}

HBV-ACLF patients ( $\mathrm{n}=201 ; 166$ males; 35 females; age 47 years) and 61 healthy subjects (23 males; 38 females; age 47 years) were included in this study. There were no significant differences among age and hepatic function parameters such as ALT, AST, alkaline phosphatase, cholinesterase, total protein, gamma-glutamyl transpeptidase, or INR among the three HBV-ACLF patient groups ( $P>0.05)$. No statistically significant differences were observed in TB and albumin (ALB) values between the normal group and the elevated group $(P>0.05)$. TB and ALB values were significantly lower in the highly elevated group than in the normal group and elevated group (both $\mathrm{P}<0.05$, Table 1). Compared with healthy subjects, serum PCT was significantly up-regulated in HBV-ACLF patients $0.1 \pm 0.1 \mathrm{ng} / \mathrm{mL}$ versus $0.9 \pm 1.3 \mathrm{ng} / \mathrm{mL}, P<0.001$, Fig. $1 \mathrm{~A}$ ).

\section{HBV-ACLF patients with higher serum PCT showed more severe renal dysfunction}

There was a significant increase in serum $\mathrm{Cr}$ levels of male and female patients in the elevated group and highly elevated group compared with those in the normal group $(\mathrm{P}<$ 0.05). In addition, serum $\mathrm{Cr}$ was significantly higher in male and female patients in the highly elevated group than in the elevated group $(\mathrm{P}<0.05)$. A significant decrease in GFR was noted in the three groups, especially the highly elevated group $(\mathrm{P}<0.05)$. Other renal function parameters including Hcy, BUN, and UA differed among these three groups (Table 1).

\section{Serum PCT was higher in HBV-ACLF patients with higher MELD score}

We classified ACLF patients into three groups according to their MELD score (ACLF1, ACLF2, and ACLF3. Table 2) and compared serum PCT levels among these groups. A significant increase in serum PCT was noted in ACLF3 compared with ACLF1 and ACLF2 (P < 0.05). No statistically significant difference was observed between ACLF1 and ACLF2 (Fig. 1B).

\section{Serum PCT was higher in HBV-ACLF patients with renal dysfunction}

To further investigate the relationship between PCT elevation and renal dysfunction, a stratified analysis was performed according to GFR ( $<60 \mathrm{~mL} / \mathrm{min}$ versus $\geq 60 \mathrm{~mL} / \mathrm{min}$ ) and serum $\mathrm{Cr}(\leq 104 \mu \mathrm{mol} / \mathrm{L}$ versus $>104 \mu \mathrm{mol} / \mathrm{L}$ in males; $\leq 84 \mu \mathrm{mol} / \mathrm{L}$ versus $>84 \mu \mathrm{mol} / \mathrm{L}$ in females). Among the patients, 33 (16.42\%) had abnormal Cr levels including 24 males with levels of $216.63 \pm 117.22 \mu \mathrm{mol} / \mathrm{L}$ and 9 females with levels of $100.30 \pm 24.08 \mu \mathrm{mol} / \mathrm{L}$. In addition, 25 patients (19 males, 6 females) had decreased GFR at a mean level of $37.19 \pm 16.41$ 
Table 1. Baseline characteristics of the patients. $\mathrm{PCT}=$ procalcitonin; $\mathrm{Cr}=$ creatinine; $\mathrm{BUN}=$ blood urea nitrogen; $\mathrm{UA}=$ uric acid; GFR = glomerular filtration rate; $\mathrm{CYC}=$ cystatin $\mathrm{C} ; \mathrm{HCY}=$ homocysteine; $\mathrm{WBC}=$ white blood cell count; $\mathrm{N} \%$ = percentage of neutrophils; ALT = alanine aminotransferase; AST = aspartate aminotransferase; $\mathrm{ALP}=$ alkaline phosphatase , $\mathrm{CHE}=$ cholinesterase; $\mathrm{TBA}=$ total bile acid; $\mathrm{TP}=$ total protein; GGT = gamma-glutamyl transpeptidase; $\mathrm{TB}=$ total bilirubin; $\mathrm{ALB}=$ albumin; $\mathrm{INR}=$ international normalized ratio; P1: elevated group versus normal group; P2: highly elevated group versus elevated group; P3: highly elevated group versus normal group; $\mathrm{P}<0.05$ was considered as significant; NA = not applicable

\begin{tabular}{|c|c|c|c|c|c|c|c|}
\hline Parameters & Normal Group & Elevated Group & $\begin{array}{c}\text { Highly elevated } \\
\text { Group }\end{array}$ & Total & P1 & $\mathrm{P} 2$ & P3 \\
\hline Sex (male) & 54 & 75 & 37 & 166 & NA & NA & NA \\
\hline Sex (female) & 20 & 10 & 5 & 35 & NA & NA & NA \\
\hline Age (years) & $45(38-57)$ & $45(36-55.5)$ & $52(41-59.25)$ & $47(38-57)$ & 0.906 & 0.107 & 0.129 \\
\hline PCT (ng/mL) & $0.34 \pm 0.11$ & $0.7 \pm 0.15$ & $2.28 \pm 2.38$ & $0.9 \pm 1.3$ & $<0.001$ & $<0.001$ & $<0.001$ \\
\hline $\mathrm{Cr}(\mu \mathrm{mol} / \mathrm{L}$, male $)$ & $62.4 \pm 13.0$ & $83.7 \pm 65.8$ & $134.5 \pm 99.7$ & $88.1 \pm 69.8$ & 0.008 & 0.007 & $<0.001$ \\
\hline $\operatorname{Cr}(\mu \mathrm{mol} / \mathrm{L}$, female $)$ & $52.7 \pm 17.99$ & $68.3 \pm 20.8$ & $108.0 \pm 35.47$ & $65.1 \pm 28.4$ & 0.042 & 0.016 & $<0.001$ \\
\hline BUN (mmol/L) & $3.94 \pm 1.68$ & $6.07 \pm 7.77$ & $10.43 \pm 8.28$ & $6.2 \pm 6.79$ & 0.016 & 0.006 & $<0.001$ \\
\hline $\mathrm{UA}(\mu \mathrm{mol} / \mathrm{L})$ & $152.7 \pm 94.43$ & $181.1 \pm 105.78$ & $267.62 \pm 182.2$ & $188.73 \pm 128.73$ & 0.078 & 0.006 & $<0.001$ \\
\hline GFR (mL/min) & $117.36 \pm 32.28$ & $104.18 \pm 28.57$ & $73.27 \pm 34.42$ & $102.86 \pm 34.96$ & 0.007 & $<0.001$ & $<0.001$ \\
\hline CYC (mg/L) & $0.98 \pm 0.38$ & $1.12 \pm 0.69$ & $1.81 \pm 1.24$ & $1.21 \pm 0.81$ & 0.143 & 0.002 & $<0.001$ \\
\hline Hсу $(\mu \mathrm{mol} / \mathrm{L})$ & $13.61 \pm 5.83$ & $17 \pm 11.06$ & $22.38 \pm 12.84$ & $16.8 \pm 10.31$ & 0.036 & 0.034 & 0.001 \\
\hline WBC $(\times 109 / \mathrm{L})$ & $6.71 \pm 3.35$ & $6.76 \pm 2.42$ & $8.81 \pm 4.6$ & $7.17 \pm 3.4$ & 0.911 & 0.009 & 0.012 \\
\hline $\mathrm{N} \%$ & $65.57 \pm 10.51$ & $65.13 \pm 10.97$ & $71.44 \pm 13.91$ & $66.62 \pm 11.7$ & 0.8 & 0.006 & 0.012 \\
\hline $\operatorname{ALT}(\mathrm{U} / \mathrm{L})$ & $446.96 \pm 658.62$ & $463.46 \pm 654.7$ & $371.81 \pm 669.57$ & $438.24 \pm 656.9$ & 0.875 & 0.463 & 0.558 \\
\hline $\operatorname{AST}(\mathrm{U} / \mathrm{L})$ & $347.2 \pm 564.03$ & $325.5 \pm 461.49$ & $246.57 \pm 304.36$ & $316.98 \pm 475.36$ & 0.79 & 0.317 & 0.287 \\
\hline ALP & $141.46 \pm 43.46$ & $135.42 \pm 35.33$ & $141.6 \pm 45.62$ & $138.94 \pm 40.61$ & 0.343 & 0.403 & 0.987 \\
\hline CHE & $3548.3 \pm 1365.2$ & $3468 \pm 1358.3$ & $3252.2 \pm 1482.3$ & $3452.8 \pm 1384.4$ & 0.712 & 0.421 & 0.284 \\
\hline TBA & $188.8 \pm 72.59$ & $187.68 \pm 68.76$ & $165.32 \pm 68.26$ & $183.51 \pm 70.37$ & 0.921 & 0.089 & 0.093 \\
\hline TP & $323.11 \pm 154.3$ & $333.3 \pm 140.98$ & $382.1 \pm 184.59$ & $339.72 \pm 156.59$ & 0.666 & 0.136 & 0.068 \\
\hline GGT (U/L) & $104.82 \pm 104.91$ & $82.15 \pm 51.31$ & $83.17 \pm 77.77$ & $90.71 \pm 80.5$ & 0.094 & 0.93 & 0.246 \\
\hline ТВ & $59.88 \pm 9.23$ & $59.6 \pm 6.84$ & $55.43 \pm 7.06$ & $58.83 \pm 8$ & 0.825 & 0.002 & 0.008 \\
\hline $\operatorname{ALB}(\mathrm{g} / \mathrm{L})$ & $32.24 \pm 4.3$ & $32.54 \pm 4.08$ & $30.82 \pm 3.93$ & $32.07 \pm 4.17$ & 0.65 & 0.026 & 0.086 \\
\hline INR & $2.26 \pm 0.98$ & $2.32 \pm 1.19$ & $2.29 \pm 0.82$ & $2.29 \pm 1.04$ & 0.7 & 0.88 & 0.842 \\
\hline
\end{tabular}

Fig. 1. Serum PCT in different groups according to MELD score. (A) Serum PCT was higher in ACLF patients than in healthy subjects $(0.9$ $\pm 1.3 \mathrm{ng} / \mathrm{mL}$ versus $0.1 \pm 0.1$ $\mathrm{ng} / \mathrm{mL}, \mathrm{P}<0.001$ ). (B) Serum PCT was higher in HBV-ACLF patients with higher MELD score, NS: no significance.

$\mathrm{mL} / \mathrm{min}$. Patients with a GFR below the cutoff value that is generally accepted as relevant for clinical decision-making showed substantially higher serum PCT levels compared with patients

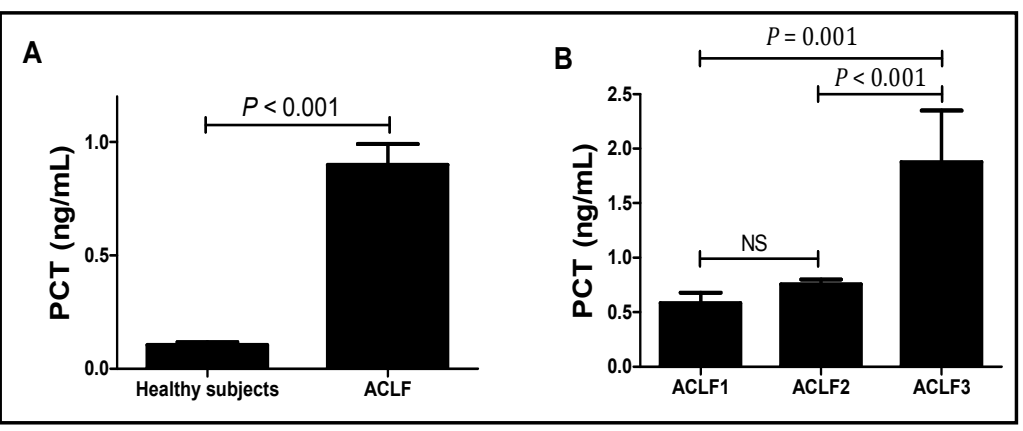

Table 2. ACLF groups based on MELD score. MELD = Model for End-stage Liver Disease; $\mathrm{N}$ = patient number

\begin{tabular}{lcccc}
\hline Groups & ACLF1 & ACLF2 & ACLF3 & Total \\
\hline MELD range & $20-29$ & $30-39$ & $\geq 40$ & \\
MELD score & $27.0 \pm 2.2$ & $34.0 \pm 2.7$ & $50.9 \pm 13.1$ & $35.0 \pm 9.7$ \\
$\mathrm{~N}$ & 54 & 113 & 34 & 201 \\
PCT $(\mathrm{ng} / \mathrm{mL})$ & $0.58 \pm 0.70$ & $0.76 \pm 046$ & $1.88 \pm 2.76$ & $0.9 \pm 1.3$ \\
\hline
\end{tabular}
with a GFR of $>60 \mathrm{~mL} /$ min $(P<0.001$, Fig. 2A). Patients with $\mathrm{Cr}$ levels above the cutoff value also had significantly higher serum PCT levels than patients with normal $\mathrm{Cr}$ levels (males, $P<0.001$; females $P=$ 0.0378, Fig. 2B-C). 


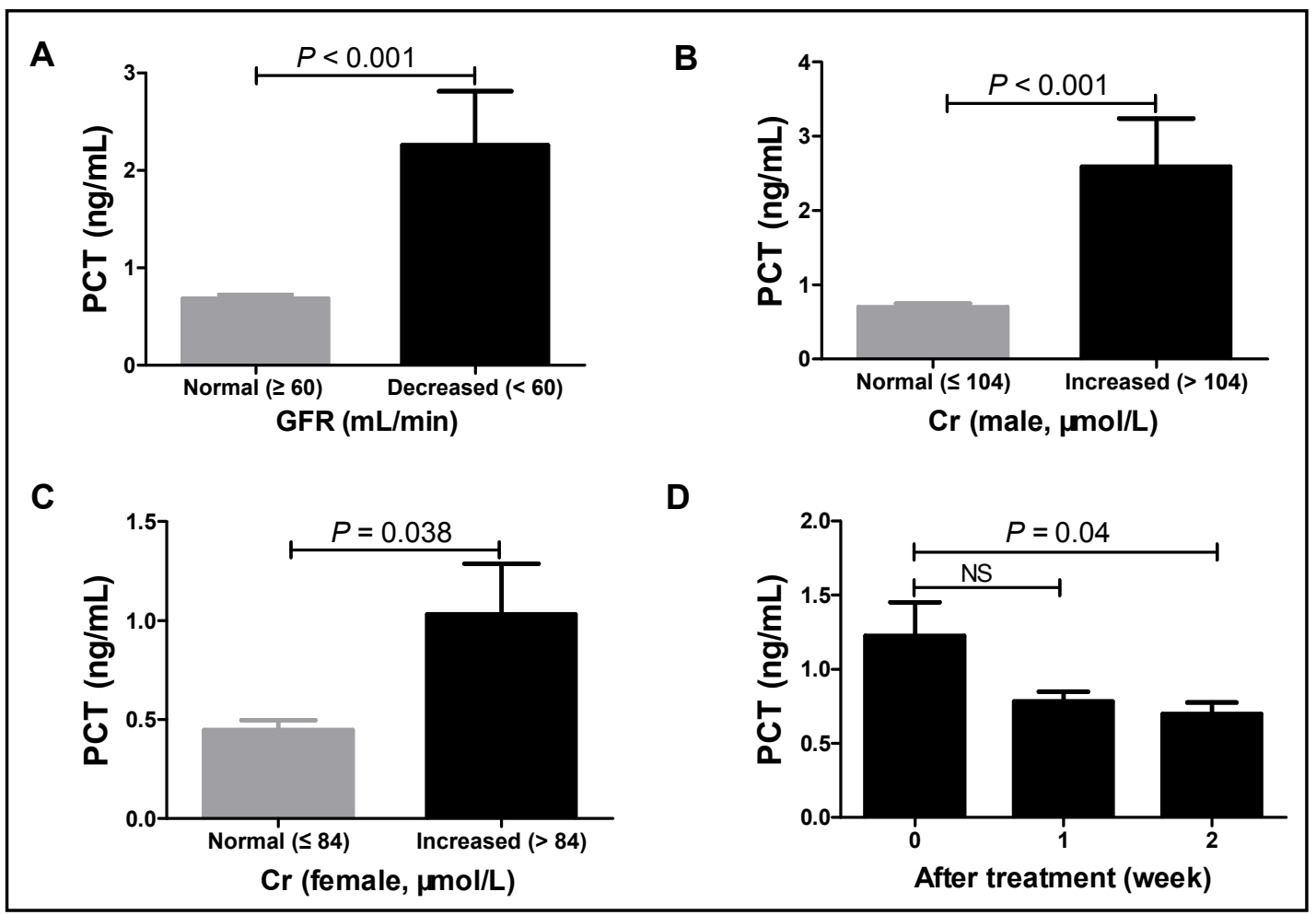

Fig. 2. Serum PCT increased in ACLF patients with renal dysfunction and decreased after treatment. (A) Serum PCT levels in patients with a GFR of $<60 \mathrm{~mL} / \mathrm{min}$ were substantially higher than in patients with a GFR of $\geq 60 \mathrm{~mL} / \mathrm{min}$. (B, C) Patients with abnormal serum Cr levels (> $104 \mu \mathrm{mol} / \mathrm{L}$ in males; $>84 \mu \mathrm{mol} / \mathrm{L}$ in females) had significantly higher serum PCT levels than the normal control. (D) Serum PCT was downregulated after 2 weeks' treatment. $\mathrm{P}<0.05$ is statistically significant, NS: no significance.

Serum PCT correlated with renal function parameters in $\mathrm{HBV}-A C L F$ patients at baseline and during treatment

Serum PCT levels correlated closely with the baseline renal function parameters including Hcy, GFR, Cr, BUN, UA and CYC (Table 3). Moreover, serum PCT and renal function were determined in the two weeks of follow-up in 35 patients $(8$ in the normal group, 15 in the elevated group, and 12 in the highly elevated group) who received standard care after admission. Our data showed that serum PCT was down-regulated (Fig. 2D), and also that it correlated with renal function parameters after 2 weeks of treatment (Table 4).

\section{Serum PCT was a risk factor for abnormal $\mathrm{Cr}$ and decreased GFR}

Since PCT showed a significant correlation with renal function parameters, we performed univariate and multivariate logistic regression analyses to identify the potential causal factors responsible for abnormal serum Cr levels (males > $104 \mu \mathrm{mol} / \mathrm{L}$; females $>84$ $\mu \mathrm{mol} / \mathrm{L}$ ) or decreased GFR ( $<60 \mathrm{~mL} / \mathrm{min}$ ) in patients with HBV-ACLF. In both univariate and multivariate analyses, PCT was a risk factor for abnormal $\mathrm{Cr}$ and lower GFR in HBV-ACLF patients (Table 5).
Table 3. Correlation between PCT and renal function parameters at baseline. Hcy = homocysteine; GFR = glomerular filtration rate; $\mathrm{Cr}=$ creatinine; $\mathrm{BUN}=$ blood urea nitrogen; $\mathrm{UA}=$ uric acid; $\mathrm{CYC}=$ cystatin $\mathrm{C}$

\begin{tabular}{lccc}
\hline Parameters & Slope & P value & 95\% CI for slope \\
\hline Hcy & 1.996 & 0.0073 & 0.5561 to 3.435 \\
GFR & -10.87 & $<0.0001$ & -14.29 to -7.458 \\
Cr (male) & 21.13 & $<0.0001$ & 14.28 to 27.98 \\
Cr (female) & 35.97 & 0.0001 & 19.26 to 52.67 \\
BUN & 1.8 & $<0.0001$ & 1.119 to 2.480 \\
UA & 39.98 & $<0.0001$ & 27.42 to 52.54 \\
CYC & 0.2385 & $<0.0001$ & 0.1582 to 0.3189 \\
\hline
\end{tabular}


High serum PCT predicted a high risk of abnormal $\mathrm{Cr}$ and lower GFR in HBV-ACLF patients

Among males, the risk of reaching the $\mathrm{Cr}$ threshold (> $104 \mu \mathrm{mol} / \mathrm{L}$ ) was significantly higher in the highly elevated group than in the normal group (45.9\% versus $1.9 \%, P<$ 0.001 ) or elevated group (45.9\% versus $8 \%, P<$ 0.001). There was no statistically significant difference between the normal group and elevated group $1.9 \%$ versus $8 \%, P$ $=0.26$ ). Similarly, the risk among the female patients was higher in the highly elevated group than in the normal group $80 \%$ versus $10 \%, P=0.002$ ). Furthermore, the risk of GFR of $<60 \mathrm{~mL} / \mathrm{min}$ was significantly higher in the highly elevated group than in the normal group $37.5 \%$ versus $4.1 \%, P<0.001$ ) and the elevated group $(37.5 \%$ versus $9.4 \%, P<0.001$ ); however, no statistically significant difference was noticed between the normal group and elevated group ( $4.1 \%$ versus $9.4 \% ; P=0.31$, Table 6$)$.

Table 4. Correlation between PCT and renal function parameters during treatment. GFR = glomerular filtration rate; $\mathrm{Cr}=$ creatinine; $\mathrm{BUN}=$ blood urea nitrogen; $\mathrm{UA}=$ uric acid; $\mathrm{CYC}=$ cystatin $\mathrm{C}$

\begin{tabular}{lcccccc}
\hline \multirow{2}{*}{ Parameters } & \multicolumn{2}{c}{ Baseline } & \multicolumn{2}{c}{ 1 week } & \multicolumn{2}{c}{2 weeks } \\
& $\mathrm{r}^{2}$ & P value & $\mathrm{r}^{2}$ & $\mathrm{P}$ value & $\mathrm{r}^{2}$ & $\mathrm{P}$ value \\
\hline GFR & 0.4763 & $<0.0001$ & 0.2608 & 0.0017 & 0.3164 & 0.001 \\
Cr & 0.5324 & $<0.0001$ & 0.3146 & 0.0005 & 0.3644 & 0.0003 \\
BUN & 0.8252 & $<0.0001$ & 0.2684 & 0.0014 & 0.563 & $<0.0001$ \\
UA & 0.5582 & $<0.0001$ & 0.2584 & 0.0018 & 0.1441 & 0.0352 \\
CYC & 0.7934 & $<0.0001$ & 0.2911 & 0.0017 & 0.4841 & $<0.0001$ \\
\hline
\end{tabular}

Table 5. Logistic regression analysis of clinical parameters to discriminate between high $\mathrm{Cr}$ (male $>104 \mu \mathrm{mol} / \mathrm{L}$, female $>84 \mu \mathrm{mol} / \mathrm{L}$ ) and low GFR $(<60 \mathrm{~mL} / \mathrm{min}$ ) in HBV-ACLF patients. Univariate and multivariate logistic regression analysis to assess factors associated with high serum $\mathrm{Cr}$ and low GFR in HBV-ACLF patients. A stepwise forward multivariate analysis including Age, PCT, TP, ALB, TBIL, WBC, and $\mathrm{N} \%$ was conducted with a probability of entry of $\mathrm{P}<0.05$ and probability of removal of $\mathrm{P}>0.1$. $\mathrm{P}<0.05$ was statistically significant. $\mathrm{PCT}=$ procalcitonin; $\mathrm{TP}=$ total protein; $\mathrm{ALB}=$ albumin $; \mathrm{TB}=$ total bilirubin; $\mathrm{WBC}=$ white blood cell count; and $\mathrm{N} \%=$ percentage of neutrophils

\begin{tabular}{lcccccc}
\hline \multirow{2}{*}{ Parameters } & \multicolumn{2}{c}{ Cr (male) } & \multicolumn{2}{c}{ Cr (female) } & \multicolumn{2}{c}{ GFR } \\
& Coefficient & P value & Coefficient & P value & Coefficient & P value \\
\hline Univariate analysis & & & & & \\
Age & 0.061 & 0.001 & 0.148 & 0.023 & 0.067 & $<0.001$ \\
PCT & 1.383 & $<0.001$ & 2.576 & 0.018 & 1.142 & 0.001 \\
TP & -0.068 & 0.019 & -0.022 & 0.681 & -0.045 & 0.097 \\
ALB & -0.164 & 0.006 & -0.151 & 0.138 & -0.215 & $<0.001$ \\
TBIL & 0.005 & $<0.001$ & -0.002 & 0.38 & 0.002 & 0.088 \\
WBC & 0.149 & 0.007 & 0.169 & 0.186 & 0.149 & 0.005 \\
N\% & 0.073 & 0.002 & 0.098 & 0.053 & 0.058 & 0.009 \\
Multivariate analysis & & & & & \\
Age & 0.075 & 0.003 & 2.171 & 0.05 & 0.078 & 0.002 \\
PCT & 1.348 & $<0.001$ & 0.143 & 0.057 & 1.072 & $<0.001$ \\
ALB & -0.239 & 0.005 & & & -0.239 & 0.002 \\
TBIL & 0.009 & $<0.001$ & & & 0.004 & 0.016 \\
Constant & -3.219 & 0.226 & & & -1.325 & 0.593 \\
\hline
\end{tabular}

\section{PCT cutoff values for evaluating renal dysfunction in HBV-ACLF patients}

The most effective PCT cutoff value for evaluating $\mathrm{Cr}$ in HBV-ACLF patients was 0.925 $\mathrm{ng} / \mathrm{mL}$ in males (AUC $=0.899$; sensitivity $87.0 \%$; specificity $80.4 \%$ ) and $0.735 \mathrm{ng} / \mathrm{mL}$ in females (AUC $=0.840$; sensitivity 77.8\%; specificity $88.5 \%$ ). Additionally, the PCT cutoff value for abnormal GFR in HBV-ACLF patients was $0.965 \mathrm{ng} / \mathrm{mL}$ (AUC $=0.810$; sensitivity $68 \%$; specificity $85 \%$; Fig. 3 ).

\section{Discussion}

HBV-ACLF is a common clinical entity of HBV-associated end-stage liver disease in China [9] and frequently progresses to renal dysfunction and even death [10]. It is therefore essential to predict the risk factors associated with survival in HBV-ACLF patients at admission. Renal dysfunction is a critical complication in HBV-ACLF patients [2]; thus, it is important to identify the factors associated with renal function to obtain a prognosis in HBVACLF. 
Table 6. The risks of abnormal $\mathrm{Cr}$ and GFR gradually increased from normal group to elevated group and highly elevated group. Chi-square tests were computed to assess the risk of $\mathrm{Cr}$ increasing in HBV-ACLF patients with higher serum PCT levels (male). ${ }^{\mathrm{m}}=$ male; ${ }^{\mathrm{f}}=$ female; ${ }^{\mathrm{a}}=$ normal group: elevated group; $^{\mathrm{b}}=$ elevated group : highly elevated group; ${ }^{c}=$ highly elevated group: normal group. $\mathrm{Cr}=$ creatinine, GFR $=$ glomerular filtration rate

\begin{tabular}{lcccc}
\hline Parameters & Normal group & Elevated group & Highly elevated group & Total \\
\hline $\mathrm{Cr}>104 \mu \mathrm{mol} / \mathrm{L}^{\mathrm{m}}$ & $1(1.9 \%)$ & $6(8.0 \%)$ & $17(45.9 \%)$ & $24(14.5 \%)$ \\
$\mathrm{Cr} \leq 104 \mu \mathrm{mol} / \mathrm{L}^{\mathrm{m}}$ & $53(98.1 \%)$ & $69(92.0 \%)$ & $20(54.1 \%)$ & $142(85.5 \%)$ \\
total & $54(100 \%)$ & $75(100 \%)$ & $37(100 \%)$ & $166(100 \%)$ \\
$\chi^{2}$ & $1.27 \mathrm{a}$ & $21.862 \mathrm{~b}$ & $26.903^{\mathrm{c}}$ & 39.13 \\
$\mathrm{P}$ & 0.26 & $<0.001$ & $<0.001$ & $<0.001$ \\
$\mathrm{Cr}>84 \mu \mathrm{mol} / \mathrm{L}^{\mathrm{f}}$ & $2(10 \%)$ & $3(30 \%)$ & $4(80 \%)$ & $9(25.7 \%)$ \\
$\mathrm{Cr} \leq 84 \mu \mathrm{mol} / \mathrm{L}^{\mathrm{f}}$ & $18(90 \%)$ & $7(70 \%)$ & $1(20 \%)$ & $25(74.3 \%)$ \\
total & $20(100 \%)$ & $10(100 \%)$ & $4(100 \%)$ & $34(100 \%)$ \\
$\chi^{2}$ & $1.813 \mathrm{a}$ & $3.506 \mathrm{~b}$ & $9.547 \mathrm{c}$ & 9.394 \\
$\mathrm{P}$ & 0.178 & 0.061 & 0.002 & $<0.001$ \\
$\mathrm{GFR}<60 \mathrm{~mL} / \mathrm{min}$ & $3(4.1 \%)$ & $7(9.4 \%)$ & $15(37.5 \%)$ & $25(13.1 \%)$ \\
$\mathrm{GFR} \geq 60 \mathrm{~mL} / \mathrm{min}$ & $71(95.9 \%)$ & $78(90.6 \%)$ & $25(62.5 \%)$ & $174(86.9 \%)$ \\
total & $74(100 \%)$ & $85(100 \%)$ & $40(100 \%)$ & $199(100 \%)$ \\
$\chi^{2}$ & $1.03 \mathrm{a}$ & $14.293 \mathrm{~b}$ & $19.401 \mathrm{c}$ & 23.207 \\
$\mathrm{P}$ & 0.31 & $<0.001$ & $<0.001$ & $<0.001$ \\
\hline
\end{tabular}

As a prohormone of calcitonin, PCT is produced by the C-cells in the thyroid gland. Circulating levels of PCT in healthy subjects are usually undetectable [11]. However, serum PCT concentrations are significantly up-regulated in patients with inflammation [12].

HBV-ACLF patients usually have elevated serum PCT levels even in the absence of infection [7]; however, the influence of elevated serum PCT on HBV-ACLF progression is not clear. Therefore, we focused on the correlation between serum PCT and renal function in HBV-ACLF patients. Renal dysfunction is a common complication in patients with HBVACLF, especially in those with marked circulatory dysfunction [13].

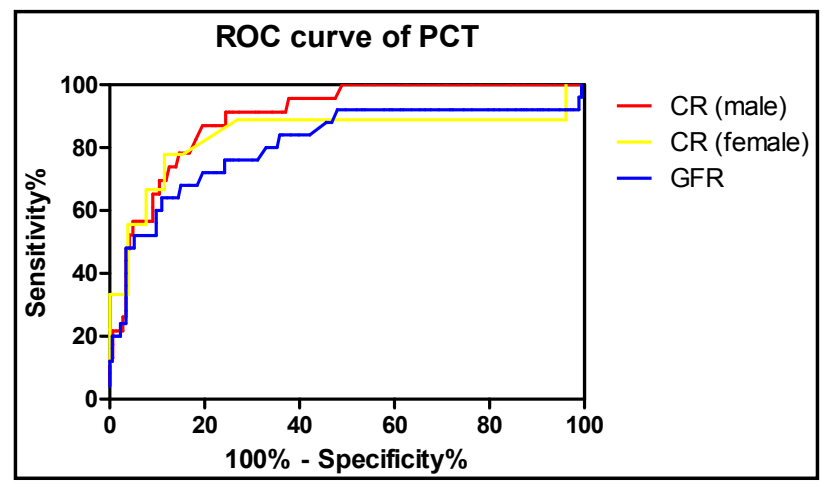

Fig. 3. ROC curve was used to calculate the AUC of individual PCT levels to discriminate between abnormal $\mathrm{Cr}$ and GFR. The most effective PCT cutoff value for $\mathrm{Cr}$ in HBV-ACLF patients was $0.925 \mathrm{ng} / \mathrm{mL}$ in males (AUC $=0.899$, sensitivity $87.0 \%$, specificity $80.4 \%$ ) and $0.735 \mathrm{ng} / \mathrm{mL}$ in females (AUC $=0.840$, sensitivity $77.8 \%$, specificity $88.5 \%$ ). For diagnosing abnormal GFR in HBV-ACLF patients, the value was $0.965 \mathrm{ng} /$ $\mathrm{mL}(\mathrm{AUC}=0.810$, sensitivity $68 \%$, specificity $85 \%$ ). Consistent with a previous report [14], our data showed that the baseline level of serum PCT was 1.8-fold higher than the upper limit $(0.5 \mathrm{ng} / \mathrm{mL})$. In addition, serum $\mathrm{Cr}$ was significantly higher and GFR was lower in HBVACLF patients with elevated serum PCT levels compared with controls. Furthermore, the other renal function parameters indicated that renal function had deteriorated alongside the elevation in serum PCT. Moreover, our study demonstrated a profound correlation between serum PCT and all renal function parameters in HBV-ACLF patients both at baseline and during treatment.

Elevated serum PCT was found to be associated with a higher mortality rate in a septic model [15], while immunoneutralization of PCT protected rats from lethal endotoxemia [6, 16]. Thus, elevated serum PCT levels were associated with the progression of sepsis. In our 
study, univariate and multivariate logistic analyses revealed that serum PCT concentration was a determinant of high serum Cr levels and low GFR, which indicated that elevated serum PCT might be one of the risk factors of renal injury in HBV-ACLF patients, just like tumour necrosis factor- $\alpha$, interleukin-6, and interleukin-1 [17]. Furthermore, among the patients with elevated serum PCT ( $>0.5 \mathrm{ng} / \mathrm{mL}$ ), most showed particularly high serum Cr levels and low GFR. Chi-square tests demonstrated that patients with elevated serum PCT were at higher risk of reaching the threshold serum $\mathrm{Cr}$ and GFR values.

Serum PCT rapidly increases in animal models after exposure to bacterial components and cytokines such as lipopolysaccharides (LPS), tumor necrosis factor- $\alpha$ (TNF- $\alpha$ ), and IL-6 [18], and our previous study proved that hepatic macrophages are the cell source of hepatic PCT in acute liver failure [19]. The inhibition of PCT expression reduces the cytokine storm and rescues a mouse sepsis model $[6,16]$. Systemic inflammation and immune system dysregulation are thought to integrate with the main physiopathological pathway involved in the natural history of HBV-ACLF [14]. Moreover, endotoxemia contributes to the activation of the innate immune system in liver failure [20]. This may explain the increase in serum PCT levels following endotoxemia and activation of the immune system in HBV-ACLF, in which serum LPS induces proinflammatory cytokines that stimulate the release of PCT, which in turn triggers the production of cytokines and causes a positive loop between PCT secretion and activation of the immune system [21]. Moreover, researchers have revealed that serum PCT levels reflect the inflammatory state and circulatory failure in HBV-ACLF patients [22]. Similarly, in this study, most patients with higher serum PCT levels showed elevated CYC levels and decreased GFR, which reflected the degree of circulatory failure.

This study had some limitations. First, it was a retrospective study from a single center. In addition, a clinical association study cannot prove a causal relationship [23]. Therefore, the suggested link between serum PCT and renal function in HBV-ACLF remains unproven. Despite these drawbacks, it is clear that serum PCT is associated with renal function in HBVACLF. Immunoneutralization of PCT will likely be a therapeutic approach for HBV-ACLF if the physiological effects can be clarified [24-26].

\section{Conclusion}

In conclusion, we demonstrated significant correlations between serum PCT and renal function parameters in HBV-ACLF patients. Elevated PCT is an alarming sign of renal dysfunction in patients with HBV-ACLF. Future studies are needed to evaluate the therapeutic value of serum PCT clearance in the progression of HBV-ACLF.

\section{Acknowledgements}

The authors thank Jian Cai and Yu Shi for their expert technical assistance. The study protocol was approved by the Ethics Committee of The First Affiliated Hospital, Zhejiang University. This study was supported by the National Natural Science Foundation of China (No. 81470851) and the 13-5 State S\&T Projects of China (No. 2018ZX10302206).

\section{Disclosure Statement}

The authors have no conflicts of interest to declare. 


\section{Cellular Physiology Cell Physiol Biochem 2018;50:1794-1803 \begin{tabular}{l|l|l}
\hline DOI: 10.1159/000494820 & ( 2018 The Author(s). Published by S. Karger AG, Basel
\end{tabular} and Biochemistry Published online: 3 November 2018 www.karger.com/cpb \\ Zheng et al.: PCT and Renal Function in HBV-ACLF}

\section{References}

1 Sarin SK, Kedarisetty CK, Abbas Z, Amarapurkar D, Bihari C, Chan AC, Chawla YK, Dokmeci AK, Garg H, Ghazinyan H, Hamid S, Kim DJ, Komolmit P, Lata S, Lee GH, Lesmana LA, Mahtab M, Maiwall R, Moreau R, Ning $Q$ et al.: Acute-on-chronic liver failure: consensus recommendations of the Asian Pacific Association for the Study of the Liver (APASL) 2014. Hepatol Int 2014;8:453-471.

-2 Angeli P, Rodriguez E, Piano S, Ariza X, Morando F, Sola E, Romano A, Garcia E, Pavesi M, Risso A, Gerbes A, Willars C, Bernardi M, Arroyo V, Gines P, Consortium CSIoE-C: Acute kidney injury and acute-on-chronic liver failure classifications in prognosis assessment of patients with acute decompensation of cirrhosis. Gut 2015;64:1616-1622.

-3 de Kruif MD, Lemaire LC, Giebelen IA, Struck J, Morgenthaler NG, Papassotiriou J, Elliott PJ, van der Poll T: The influence of corticosteroids on the release of novel biomarkers in human endotoxemia. Intensive Care Med 2008;34:518-522.

4 de Jong E, van Oers JA, Beishuizen A, Vos P, Vermeijden WJ, Haas LE, Loef BG, Dormans T, van Melsen GC, Kluiters YC, Kemperman H, van den Elsen MJ, Schouten JA, Streefkerk JO, Krabbe HG, Kieft H, Kluge GH, van Dam VC, van Pelt J, Bormans L et al.: Efficacy and safety of procalcitonin guidance in reducing the duration of antibiotic treatment in critically ill patients: a randomised, controlled, open-label trial. Lancet Infect Dis 2016;16:819-827.

-5 Nylen ES, Whang KT, Snider RH, Jr., Steinwald PM, White JC, Becker KL: Mortality is increased by procalcitonin and decreased by an antiserum reactive to procalcitonin in experimental sepsis. Crit Care Med 1998;26:1001-1006.

6 Tavares E, Minano FJ: Immunoneutralization of the aminoprocalcitonin peptide of procalcitonin protects rats from lethal endotoxaemia: neuroendocrine and systemic studies. Clin Sci (Lond) 2010;119:519-534.

$>7$ Qu J, Feng P, Luo Y, Lu X: Impact of hepatic function on serum procalcitonin for the diagnosis of bacterial infections in patients with chronic liver disease: A retrospective analysis of 324 cases. Medicine (Baltimore) 2016;95:e4270.

>8 Wiesner R, Edwards E, Freeman R, Harper A, Kim R, Kamath P, Kremers W, Lake J, Howard T, Merion RM, Wolfe RA, Krom R, United Network for Organ Sharing Liver Disease Severity Score Committee: Model for end-stage liver disease (MELD) and allocation of donor livers. Gastroenterology 2003;124:91-96.

-9 Xie GJ, Zhang HY, Chen Q Liu HM, You JP, Yang S, Mao Q, Zhang XQ: Changing etiologies and outcome of liver failure in Southwest China. Virol J 2016;13:89.

10 Arroyo V, Moreau R: Diagnosis and prognosis of acute on chronic liver failure (ACLF) in cirrhosis. J Hepatol 2016;10.1016/j.jhep.2016.10.012.

11 Niederman MS: Serum procalcitonin and the admission decision in CAP. Lancet Respir Med 2016;4:956.

12 Maruna P, Nedelnikova K, Gurlich R: Physiology and genetics of procalcitonin. Physiol Res 2000;49 Suppl $1:$ S57-61.

13 Salerno F, Gerbes A, Gines P, Wong F, Arroyo V: Diagnosis, prevention and treatment of hepatorenal syndrome in cirrhosis. Postgraduate Medical Journal 2008;84:662-670.

14 Dirchwolf M, Ruf AE: Role of systemic inflammation in cirrhosis: From pathogenesis to prognosis. World J Hepatol 2015;7:1974-1981.

-15 Steinwald PM, Whang KT, Becker KL, Snider RH, Nylen ES, White JC: Elevated calcitonin precursor levels are related to mortality in an animal model of sepsis. Crit Care 1999;3:11-16.

-16 Tavares E, Maldonado R, Minano FJ: Immunoneutralization of endogenous aminoprocalcitonin attenuates sepsis-induced acute lung injury and mortality in rats. Am J Pathol 2014;184:3069-3083.

17 Moore JK, Love E, Craig DG, Hayes PC, Simpson KJ: Acute kidney injury in acute liver failure: a review. Expert Rev Gastroenterol Hepatol 2013;7:701-712.

18 Linscheid P, Seboek D, Nylen ES, Langer I, Schlatter M, Becker KL, Keller U, Muller B: In vitro and in vivo calcitonin I gene expression in parenchymal cells: a novel product of human adipose tissue. Endocrinology 2003;144:5578-5584.

19 Zheng W, Ye B, Liang X, Shui L, Lou G, Liu Y, Zheng M: Hepatic Macrophages are the Cell Source of Hepatic Procalcitonin in Acute Liver Failure. Cell Physiol Biochem 2018;47:1133-1140. 


\section{Cellular Physiology Cell Physiol Biochem 2018;50:1794-1803

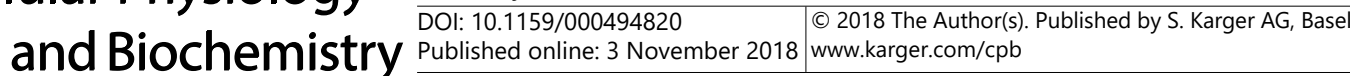 \\ Zheng et al:: PCT and Renal Function in HBV-ACLF}

-20 Lee KC, Baker LA, Stanzani G, Alibhai H, Chang YM, Jimenez Palacios C, Leckie PJ, Giordano P, Priestnall SL, Antoine DJ, Jenkins RE, Goldring CE, Park BK, Andreola F, Agarwal B, Mookerjee RP, Davies NA, Jalan R: Extracorporeal liver assist device to exchange albumin and remove endotoxin in acute liver failure: Results of a pivotal pre-clinical study. J Hepatol 2015;63:634-642.

21 Matwiyoff GN, Prahl JD, Miller RJ, Carmichael JJ, Amundson DE, Seda G, Daheshia M: Immune regulation of procalcitonin: a biomarker and mediator of infection. Inflamm Res 2012;61:401-409.

-22 Tavares E, Maldonado R, Ojeda ML, Minano FJ: Circulating inflammatory mediators during start of fever in differential diagnosis of gram-negative and gram-positive infections in leukopenic rats. Clin Diagn Lab Immunol 2005;12:1085-1093.

-23 Farnik H, Bojunga J, Berger A, Allwinn R, Waidmann O, Kronenberger B, Keppler OT, Zeuzem S, Sarrazin C, Lange CM: Low vitamin D serum concentration is associated with high levels of hepatitis B virus replication in chronically infected patients. Hepatology 2013;58:1270-1276.

24 Liu HH, Guo JB, Geng Y, Su L: Procalcitonin: present and future. Ir J Med Sci 2015;184:597-605.

-25 Shi L, Lehto SG, Zhu DX, Sun H, Zhang J, Smith BP, Immke DC, Wild KD, Xu C: Pharmacologic Characterization of AMG 334, a Potent and Selective Human Monoclonal Antibody against the Calcitonin Gene-Related Peptide Receptor. J Pharmacol Exp Ther 2016;356:223-231.

-26 Kuzawinska O, Lis K, Cessak G, Mirowska-Guzel D, Balkowiec-Iskra E: Targeting of calcitonin gene-related peptide action as a new strategy for migraine treatment. Neurol Neurochir Pol 2016;50:463-467. 